\title{
Dyskusje o szkolnictwie polskim okresu międzywojennego na łamach jezuickiego „Przeglądu Powszechnego" w latach 1918-1939
}

W całym okresie Drugiej Rzeczypospolitej szeroko pojęta problematyka edukacji stanowiła przedmiot zainteresowania wielu redakcji gazet i czasopism ${ }^{1}$. Informacje, wypowiedzi i rozważania na ten temat zamieszczano w periodykach środowisk naukowo i zawodowo związanych z oświatą, wydawnictwach sfer rządzących i ugrupowań politycznych pozostających do nich w opozycji, pismach stowarzyszeń i firm edytorskich, które adresowano do określonych grup inteligencji oraz do rodziców i kobiet. Sporo miejsca na refleksje i przemyślenia w tym zakresie przeznaczano także w czasopismach organizacji i szeregu związków wyznaniowych ${ }^{2}$. Niemało tego typu treści można odnaleźć w pismach Kościoła katolickiego ${ }^{3}$, który kształcenie i wychowanie młodego pokolenia uznawał za jedną z najważniejszych kwestii w swojej duszpasterskiej działalności w Polsce. O wyjątkowej i niezastępowalnej przez inne podmioty roli instytucji Kościoła

* Dr hab., prof. nadzw. UŁ, kierownik Katedry Historii Wychowania i Pedeutologii, Wydział Nauk o Wychowaniu, Uniwersytet Łódzki, 91-408 Łódź, ul. Pomorska 46/48.

1 Zob. np. Czasopiśmiennictwo okresu Drugiej Rzeczypospolitej jako źródło do historii edukacji, red. I. M i c h a I s k a, G. M i c h a I s k i, Łódź 2010.

2 Zob. np. T. M a m e s, Praktyka i ideologia oświatowa Kościoła Starokatolickiego Mariawitów (1906-1935), mpis rozprawy doktorskiej napisanej pod kierunkiem prof. dr. hab. Andrzeja M. de Tchorzewskiego, Uniwersytet Łódzki, Wydział Nauk o Wychowaniu, Łódź 2010.

${ }^{3}$ Kościół katolicki jako instytucja był wydawcą w 1936 r. około 200 tytułów prasowych, a ich łączny nakład wynosił ponad $25 \%$ całości nakładów periodyków w Polsce. Do wspomnianej liczby tytułów trzeba doliczyć jeszcze około kilkudziesięciu, którym Kościół bezpośrednio patronował. Zob. J. Ło j e k, J. M y ś l iń s k i, W. Wła d y k a, Dzieje prasy polskiej, Warszawa 1988, s. 114-115. Problemy oświaty i szkolnictwa przede wszystkim podejmowano na łamach takich periodyków, jak: „Przegląd Powszechny”, „Przegląd Katolicki”, „Miesięcznik Katechetyczny i Wychowawczy”, „Ateneum Kapłańskie”, „Kultura”, „Kronika Diecezji Kujawsko-Kaliskiej”, „Kronika Diecezji Sandomierskiej”, „Przegląd Diecezjalny” [Kielecki], „Przewodnik Katolicki”, „Wiadomości dla Duchowieństwa”, „Dzwon Niedzielny”, „Miesięcznik Pasterski Płocki”, „Wiadomości Diecezji Lubelskiej”, „Gazeta Kościelna”, „Sodalis Marianus”, „Wiadomości Diecezjalne Podlaskie”, „Miesięcznik Diecezji Chełmińskiej”, „Wiara i Życie”. 
w dziedzinie szkolnictwa, arcybiskup Iwowski Józef Bilczewski tak pisał: „[...] rząd państwowy obowiązany jest darzyć pełnym zaufaniem i opieką Kościół katolicki, który jest głosicielem, tłumaczem, stróżem całej czystej prawdy i etyki chrześcijańskiej i ułatwiać mu jego wprost od Boga zawierzone mu posłannictwo nauczania i religijno-moralnego wychowania młodzieży tak w murach świątyń, jak i w szkołach prywatnych i publicznych"4.

W propagowanie doktryny i stanowiska Kościoła wobec wszystkich sfer życia publicznego aktywnie włączył się w latach międzywojennych jezuicki miesięcznik społeczno-kulturalny „Przegląd Powszechny”, któremu przypisywano wówczas szczególne i wyjątkowe znaczenie w tym obszarze działalności. Wynikało to nie tyle z wielkości nakładu, bo w stosunku do innych pism katolickich był on niewielki ${ }^{5}$, lecz z typu jasno określonego adresata, jakim była inteligencja, od której w pierwszym rzędzie zależał aktualny i przyszły kształt państwa. Dążąc do zaspokojenia oczekiwań i potrzeb intelektualnych tej grupy społecznej, z jednej strony zamieszczano na łamach tego czasopisma obszerne teksty z dziedziny filozofii i etyki, teologii i kultury, historii i literatury, z drugiej natomiast - szereg artykułów dotyczących aktualnych kwestii państwowych, społecznych, kulturalnych i oświatowych, które dodatkowo miały na celu ukształtowanie w tych sprawach katolickiego poglądu na świat. Warto zauważyć, że takie zadanie postawiono przed tym wydawnictwem już w momencie powołania go do życia w 1884 r. W słowie wstępnym o. Marian Morawski pisał: „Zakreślamy sobie plan następujący. Przede wszystkim podnosić i opracowywać chcemy zasadnicze kwestie społeczne, tj. zagadnienia i interesa, które w życiu społeczeństw mają właściwe pole, ale korzeni szukać trzeba w religii i filozofii, a ostatnie wyniki spotyka się w ekonomii i polityce. Obok [...] kwestii ogólnych i zasadniczych, podejmować także chcemy praktyczne sprawy i interesa na krajowym gruncie z dnia na dzień powstające, jak sprawy naszych szkół, stowarzyszeń, instytucji dobroczynnych itp. czynników spółecznego życia" 6 .

Z analizy zawartości wszystkich międzywojennych roczników „Przeglądu Powszechnego" wynika, że w tym czasie redaktorzy ${ }^{7}$ wielką wagę przywiązywali do zagadnień związanych ze szkolnictwem w Polsce. W regularnie drukowanych na ten temat artykułach, których autorami byli wybitni znawcy problematyki ${ }^{8}$, nie

${ }^{4}$ J. B ilc z e w s k i, Listy pasterskie, odezwy, kazania i mowy okolicznościowe [Ten i kolejne cytaty zachowały oryginalną pisownię.], t. 3, Lwów 1924, s. 238.

${ }^{5}$ Pod koniec lat trzydziestych wynosił on 1800 egzemplarzy. Dla porównania warto przykładowo przytoczyć wielkość nakładu kilku innych periodyków katolickich: „Rycerz Niepokalanej” 730 tys. Egzemplarzy, „Przewodnik Katolicki” 220 tys. egzemplarzy, „Posłaniec Serca Jezusowego” 130 tys. egzemplarzy, „Przegląd Katolicki” 75 tys. egzemplarzy, „Gość Niedzielny” 45 tys. egzemplarzy, „Niedziela” 10 tys. egzemplarzy. Zob. J. G ó r a I, Wydawnictwa i prasa katolicka, [w:] Kościół katolicki w Polsce 1918-1990, red. L. A d a m c z u k, W. Z d a n o w i c z, Warszawa 1991.

6 M. M or a w s k i, Cele i zadania „Przeglądu Powszechnego”, „Przegląd Powszechny” [dalej: PP] 1884, nr 1, s. 3.

7 Kolejno redaktorami naczelnymi byli: Jan Urban (1918-1933), Jan Rostworowski (1933-1936), Edward Kosibowicz (1936-1939).

8 Zob. A. Ż a k, Pedagogika i szkolnictwo w „Przeglądzie Powszechnym”, [w:] Wydawnictwo Apostolstwa Modlitwy 1872-1992: historia, opracowania, bibliografia, red. Z. W i I k o s z, L. G r z e b i e ń, Kraków 1992, s. 184-186. 
tylko konsekwentnie przeprowadzano ocenę rzeczywistości oświatowej w duchu oficjalnej nauki Kościoła, ale ukazywano także, jakie działania i w jakim zakresie należy podjąć, aby nadać polskiej szkole charakter zgodny ze światopoglądem wyznawców katolicyzmu, stanowiących w Polsce większość mieszkańców ${ }^{9}$. Zdecydowanie odrzucano więc jakiekolwiek warianty szkoły świeckiej. Pogląd na ten temat redakcja sformułowała już w 1918 r. i stanowił wówczas reakcję na zamiary oświatowe rządu lubelskiego Ignacego Daszyńskiego, a następnie rządu J. Moraczewskiego, który w „Odezwie do Narodu” z 20 listopada 1918 r. zapowiedział utworzenie w Polsce świeckiej i bezpłatnej szkoły, łatwo i szeroko dostępnej dla wszystkich dzieci niezależnie od ich wyznania i stanu majątkowego. Należy zauważyć, że projekt takiej szkoły biskupi polscy przyjęli jako zamach na prawa i obowiązki Kościoła katolickiego w dziedzinie szkolnictwa. Uznając propozycję za niebezpieczną dla wychowania katolickiego, na początku grudnia 1918 r. wystosowali specjalny list do wiernych, ukazując niebezpieczeństwa - jak to nazywano - socjalistycznej ideologii, która przeciwstawia się tradycji katolickiej Polski i dąży do odebrania życiu publicznemu, w tym szkolnictwu, religijnego charakteru. Zgadzając się z tak postawioną tezą, na łamach czasopisma twierdzono, że taka szkoła, wychowując w jednej grupie uczniów pochodzących z rodzin o różnych światopoglądach, wyklucza z programu kształcenia nie tylko nauczanie religii, ale jakiekolwiek odniesienia do Boga i wiary ${ }^{10}$. Zauważano ponadto, że w szkołach tego typu lekcje religii i etyki zastępuje się zajęciami „moralności niezależnej”, która jest obdarta z „nadprzyrodzonego nimbu” i w żadnym stopniu nie uwzględnia praw oraz sankcji Bożych. Takie podejście do wychowania określano jako szkodliwe dla przyszłości państwa i życia społecznego, bo doprowadza nie tylko do indyferentyzmu religijnego, ale wprost do ateizmu, przejawiającego się w niemożliwym do zaakceptowania powszechnym relatywizmie i obojętności wobec rzeczywistości oraz w postawie egoizmu w relacjach z innymi ludźmi ${ }^{11}$. Aby przestrzec czytelników przed skutkami, jakie przynosi działalność szkoły świeckiej, przywoływano z jednej strony przykład Francji, gdzie taka szkoła funkcjonuje, twierdząc, że w ostatnich dziesiątkach lat wzrosły w tym kraju do niebywałych rozmiarów przestępstwa wśród młodzieży, z drugiej - Rosji sowieckiej, która w tym typie szkoły wychowuje pokolenie młodych bezbożników, by bez żadnych skrupułów mogło ono realizować program bolszewickiego przewrotu ${ }^{12}$. Odnosząc się do

${ }^{9}$ Z danych z 1931 r. sporządzonych na podstawie spisu ludności wynika, że w Polsce wyznanie rzymsko-katolickie deklarowało 64,8\% ogółu mieszkańców, prawosławne - 11,8\%, grekokatolickie 10,4\%, mojżeszowe - 9,8\%, ewangelickie - 2,6\%, inne - 0,6\%. Zob. H. Z i e l i ń s k i, Historia Polski 1914-1939, Wrocław-Warszawa-Kraków-Gdańsk-Łódź 1983, s. 126.

10 J. U r b a n, O szkołę katolicką, PP 1919, t. 141-142, s. 81-83 i 86-87; S. P o d o l e ń s k i, Kościół a szkoła, PP 1930, t. 186, s. 170. W tym kontekście oceniano także pruską reformę szkolną. Stwierdzano: „Nowy program szkolny jest typowym owocem nowoczesnych pogańskich poglądów na wychowanie i szkołę, łącznie z omnipotencją państwa w tej dziedzinie”. Zob. S. B e d n a r s k i, Pruska reforma szkolna z 13 marca 1924 roku, PP 1924, t. 163, s. 179-181.

11 J. U r b a n, O szkołę katolicką..., s. 85.

12 Tamże, s. 86 oraz: Sprawy Kościoła. W kwestii monopolu szkolnego. Zagrożony los prywatnego szkolnictwa w Polsce, PP 1933, t. 200, s. 297; S. P o d o l e ń s k i, Szkolnictwo i wychowanie w Rosji bolszewickiej, PP 1925, t. 165, s. 121-128. 
poglądów zwolenników szkoły świeckiej, sformułowano następujące stanowisko: „Tak niebezpiecznie eksperymentować z duszą dziecka nie chcemy i dlatego na szkołę świecką wprost w naszym katolickim społeczeństwie w przyszłości miejsca być nie może. W miarę budowania takich szkół, musielibyśmy budować i rozszerzać kryminały. I niech nikt nie mówi, że brak religii w szkole można zastąpić nauczaniem religijnym dzieci i młodzieży w kościele. Najpierw bowiem, przy rozległości polskich parafii, świątynia bynajmniej nie nadaje się na dogodne centrum dla ściągania dziatwy na stałą naukę katechizmu; po wtóre, i to najważniejszy wzgląd, że religia w oczach nie tylko dziecka, ale i dorosłego prostaczka straci na powadze, skoro będzie usunięta ze szkoły przez tych, co rządzić będą narodem, a może i wyśmiewana w szkole przez tych, których za wyrazicieli nauki uważać się będzie"13.

Nie wyrażając zgody na szkołę świecką w Polsce, na łamach „Przeglądu Powszechnego" przez cały okres międzywojenny propagowano ideę szkoły religijnej katolickiej ${ }^{14}$, która jako jedyna mogła zrealizować „boską misję Kościoła w wychowaniu"15 i zagwarantować mu maksymalny wpływ na proces edukacji zarówno w sferze programowej, jak i instytucjonalnej. Opierając się na zapisach prawa kanonicznego ${ }^{16}$, encyklice 0 chrześcijańskim wychowaniu młodzieży ${ }^{17}$ oraz

${ }^{13}$ J. U rba n, O szkołę katolicką..., s. 86. Zob. także: Orędzie biskupów polskich do duchowieństwa i wiernych z 10 grudnia 1918 r., [w:] Metropolia warszawska a narodziny II Rzeczypospolitej, red. M. M. D r o z d o w s k i, Warszawa 1998, s. 146-163. Trzeba ponadto zauważyć, że w obronie przed zakusami wprowadzenia w Polsce szkoły świeckiej już w marcu 1919 r. Episkopat powołał specjalną Komisję Szkolną, która sformułowała postulaty Kościoła dotyczące oświaty, uznając za sprawę najważniejszą walkę o szkołę wyznaniową. Zob. J. S z c z e p a n i a k, Troska Kościoła katolickiego o nauczanie i wychowanie religijne w Polsce w latach 1918-1927, Kraków 1997, s. 97-102.

${ }^{14}$ Aby przekonać czytelników, że polskie dążenia do ustanowienia szkoły religijnej katolickiej nie mają wyłącznie lokalnego charakteru, drukowano artykuły przedstawiające, jak wygląda sytuacja w tym zakresie w innych krajach. Zob. np. S. P o d o l e ń s k i, Szkolnictwo katolickie w Holandii, PP 1920, t. 147-148, s. 269-272; t e n ż e, Katolicy świata wobec szkoły katolickiej, PP 1921, t. 149-150, s. 350-363; L. de C o n i n c k, Katolickie szkolnictwo w Belgii, tamże, s. 391-405; J. U r b a n, Sprawy Kościoła. Walka o konkordat i szkołę wyznaniową, PP 1927, t. 176, s. 113-116; H. K o w n a c k a, Rozwój szkolnictwa katolickiego w Stanach Zjednoczonych, PP 1931, t. 190, s. 254-255; S. P o d o I e ń s k i, Z walk o katolicką szkołę w Austrii, PP 1935, t. 206.

${ }^{15}$ Określenie ordynariusza Iwowskiego Józefa Bilczewskiego. Zob. A. M a z a n, Pedagogia Związku Sodalicji Mariańskich uczniów szkół średnich w latach 1919-1939, mpis rozprawy doktorskiej napisanej pod kierunkiem ks. prof. dr. hab. Jerzego Kołaczkowskiego, Uniwersytet Pedagogiczny im. Komisji Edukacji Narodowej w Krakowie, Kraków 2008, s. 46-47.

${ }^{16}$ Chodzi o Kodeks Prawa Kanonicznego ogłoszony w 1917 r. przez Papieża Benedykta XV, który w kanonie 1374. zawierał zakaz posyłania dzieci katolickich do szkół niekatolickich, neutralnych i mieszanych. Mógł on zostać uchylony jedynie w nadzwyczajnych okolicznościach, a decyzja w tym zakresie należała do biskupa. Szerzej na ten temat pisze: J. S z c z e p a n i a k, Episkopat w obronie katolickiego charakteru polskiej szkoły 1927-1937, Kraków 2000, s. 31

17 Encyklikę tę ogłosił w 1929 r. Pius XI. Papież napisał w niej: „Nie przez to samo, że w szkole udziela się (często bardzo skąpo) nauki religii, staje się ona zgodną z prawami Kościoła i chrześcijańskiej rodziny i godną, by do niej uczęszczali katoliccy uczniowie. By ona była taką, potrzeba, aby całe nauczanie i całe urządzenie szkoły: nauczyciele, programy, podręczniki do wszystkich przedmiotów były przejęte chrześcijańskim duchem, pod macierzyńskim kierunkiem i czujnością Kościoła w ten sposób, żeby religia była prawdziwie podstawą i uwieńczeniem całego wykształcenia, na wszystkich stopniach, nie tylko początkowych, ale i średnich i wyższych. Konieczną jest rzeczą - żeby użyć słów 
listach pasterskich i przemówieniach biskupów polskich ${ }^{18}$, wyjaśniano, że jest to najlepszy typ szkoły dla dzieci katolickich rodzin, ponieważ zapewnia ochronę przed negatywnymi wpływami innowierców, przeprowadza jednolite oddziaływania wychowawcze dzięki zatrudnianiu nauczycieli tego samego wyznania, a także religii jako centralnego przedmiotu nauczania ${ }^{19}$; stoi na „straży nauki Chrystusa” przez niedopuszczanie do nauczania przedmiotów pozostających w sprzeczności z zasadami katechezy; troszczy się o właściwe miejsce praktyk i ćwiczeń religijnych w realizacji programu kształcenia ${ }^{20}$. Czytelników przekonywano: „Taka dopiero szkoła - szkoła katolicka, czyli wyznaniowa - odpowiada w pełni życzeniom Kościoła i prawom rodziców. Taką też szkołę [...] popiera Kościół, każe katolikom dążyć wszędzie do jej zdobycia i nie szczędzić w tym celu żadnych ofiar. [...] Warunkiem bowiem powodzenia w działalności wychowawczej jest jednolitość kierunku i wpływu wszystkich wychowawców, oraz tych środowisk, w jakich się dziecko obraca. Otóż dla dziecka katolickiego wychowawcami tymi są rodzice, Kościół i nauczycielstwo, środowiskiem zaś wychowawczym jest dom rodzinny, Kościół i szkoła. Musi więc między nimi panować jedność, i im ta harmonia będzie doskonalsza, tym lepsze będą wyniki wychowania"21.

Przedstawiany w „Przeglądzie Powszechnym” model szkoły katolickiej stanowił dla publicystów tego czasopisma merytoryczną podstawę odniesień w rozważaniach na temat szkoły międzywyznaniowej. Niezależnie od tego, że ten typ instytucji edukacyjnej pozostawiał religię jako przedmiot kształcenia, nie traktowano jej jako odpowiedniej dla dzieci katolickich, ponieważ uczęszczają do niej uczniowie różnych konfesji i uczą w niej innowierczy nauczyciele, którzy w żaden sposób nie mogą zapewnić jednolitości oddziaływań wychowawczych ${ }^{22}$. Pogląd

Leona XII - «by nie tylko w pewnych godzinach wykładało się młodzieży religię, ale aby całe nauczanie tchnęło duchem chrześcijańskiej pobożności». Jeżeli tego braknie, jeśli to święte tchnienie, nie będzie przenikać i rozgrzewać dusz nauczycieli i uczniów, bardzo mały pożytek będzie można zebrać z jakiejkolwiek nauki; przeciwnie często wynikną z tego szkody i to niemałe".

18 Zob. np. S. W i I k, Episkopat Kościoła Katolickiego w Polsce w latach 1918-1939, Warszawa 1992.

${ }^{19}$ Ks. Jan Urban jako jedyny publicysta czasopisma dopuszczał możliwość wykładania w szkole katolickiej niektórych przedmiotów przez nauczycieli niekatolików. Zaliczył do nich gramatykę i matematykę, uznając, że nie mają związku z poglądami religijnymi. Zob. J. U r b a n, O szkołę katolicką..., s. 83.

20 Tamże, s. 84; E. K o s i b o w i c z, Sprawy Kościoła. Rozprzężenie moralne wśród młodzieży. Konstytucyjna i okólnikowa teoria a praktyka. Przepisy prawa kościelnego. Postulat szkoły wyznaniowej, PP 1937, t. 213, s. 253-254.

21 S. P o d o l e ń s k i, Kościół a szkoła..., s. 169-170.

22 Starania Kościoła zmierzające do nadania szkole katolickiego charakteru znalazły częściowe urzeczywistnienie w Konstytucji uchwalonej 21 marca 1921 r. Co prawda, nie wpisano do niej oczekiwania, aby szkoły państwowe były jednolite pod względem wyznaniowym, jednak w artykule 120. wprowadzono obowiązek nauczania religii w szkołach powszechnych i średnich. Zob. J. S z c z e p a n i a k, Troska kościoła o nauczanie i wychowanie religijne w Polsce w latach 1918-1939, Kraków 1997, s. 138-149. Należy ponadto zauważyć, że kolejną batalię o wpisanie do Konstytucji wyznaniowości szkoły Kościół przeprowadził w następnych latach, kiedy prowadzono prace nad zmianami jej zapisów. Jednak nie przyniosła ona oczekiwanych rezultatów i Konstytucja z 23 kwietnia 1935 r. zachowała wcześniejsze zapisy dotyczące charakteru polskiej szkoły. Zob. J. S z c z e p a n i a k, Episkopat w obronie katolickiego charakteru..., s. 105-114. 
ten podtrzymywano nawet po podpisaniu konkordatu ze Stolicą Apostolską 23 i ogłoszeniu w 1926 r. rozporządzenia ministra WRiOP o nauce religii katolickiej (tzw. okólnik Bartla) ${ }^{24}$, które nie tylko potwierdzało konstytucyjną obligatoryjność nauki religii, ale stanowiło ponadto o obowiązkowych praktykach religijnych jako integralnej części nauczania i wychowania religijnego. Ustalało także, że księża prefekci są duszpasterzami młodzieży w zakresie życia szkolnego, co w praktyce oznaczało, że posiadali prawo udziału we wszystkich gremiach zajmujących się sprawami wychowania ${ }^{25}$. O niedostatkach rozwiązań prawnych w dziedzinie szkolnictwa tak pisał w połowie lat dwudziestych XX w. jeden z autorów: „Trzeba będzie dopiero dłuższej pracy uświadamiającej, a kto wie, czy nie popartej smutnymi doświadczeniami, by ogół katolickiego społeczeństwa polskiego zrozumiał, że szkoła międzywyznaniowa (symultanna) nie jest wystarczającą, ponieważ zabezpiecza katolickie wychowanie o tyle, o ile personel nauczycielski podziela sercem i czynem te zapatrywania, ale zostawia również otwartą drogę do wyrywania wiary z serc młodzieży z chwilą, w której mała nawet część grona nauczycielskiego będzie usposobiona wrogo dla Kościoła"26.

Przywołując w połowie lat trzydziestych doświadczenia z działalności szkół mieszanych, w „Przeglądzie Powszechnym” sformułowano stanowisko, że wszystkie decyzje dotyczące reform szkolnych w Polsce lekceważyły postulaty Kościoła katolickiego i miały charakter wyłącznie polityczno-ideologiczny, co skutkowało odrzuceniem innych, ważnych i istotnych uwarunkowań, przede wszystkim narodowo-katolickich. W sposób otwarty twierdzono, że rezultatem pierwszej reformy szkolnej było utworzenie szkoły międzywyznaniowej i jednolitej dla wszystkich, szkoły - jak to określano - „bezwyrazowej”, ponieważ równała wszystkie wyznania, narodowości, a nawet płeć. Takie rozstrzygnięcia prawne traktowano jako działanie przeciwko tradycji narodowej i walkę z Kościołem katolickim, który w dziedzinie wychowania powinien mieć szczególne i niezastępowane prawa. Równie krytycznie oceniano reformę Janusza Jędrzejewicza, która dodatkowo jeszcze narzuciła szkołom państwowym i prywatnym formułę polityczną wychowania państwowego i przekreśliła naturalne prawo rodziny oraz innych środowisk do decydowania o kierunku i treściach wychowania dzieci i młodzieży. Pod koniec lat trzydziestych XX w. publicyści „Przeglądu Powszechnego” adresowali do władz oświatowych propozycje konkretnych rozwiązań szkolnych, które ich zdaniem zapewnią w przyszłości właściwy kształt ustroju szkolnego i wyelimi-

${ }^{23}$ Zob. np. S. Ł u k o m s k i, Konkordat Polski ze Stolicą Apostolską, Lwów 1925, s. 46; W. W ó j c i k, Konkordat Polski z 1925 r. Próba oceny, [w:] Kościół w Il Rzeczypospolitej, red. Z. Z i e I i ń s k i, S. W i I k, Lublin 1981, s. 15-35.

${ }^{24}$ S. P o d o I e ń s k i, Sprawa praktyk religijnych w szkole, PP 1927, t. 174, s. 140-144; Sprawy Kościoła. Dekret ministerialny o nauczaniu religii w naszych szkołach, tamże, t. 173, s. 258-260.

${ }^{25}$ Praktyki religijne zostały wprowadzone do wszystkich szkół od początków niepodległości. Zajęciami obowiązkowymi stały się częściowo już w 1922 r. na mocy rozporządzenia ministra WRiOP K. Kumanieckiego. Zob. S. W i I k, Episkopat Kościoła katolickiego..., s. 286; L. G r o c h o w s k i, Wychowanie religijne katolickie w szkołach II Rzeczypospolitej lat dwudziestych. Treści i funkcje, [w:] Katolicka a liberalna myśl wychowawcza w Polsce w okresie międzywojennym. Zagadnienia wybrane, red. ks. E. W a I e w a n d e r, Lublin 2000, s. 244.

${ }^{26}$ S. P o d o l e ń s k i, Konkordat a szkoła i wychowanie, PP 1925, t. 166, s. 132-133. 
nują wszystkie błędy wcześniejszych decyzji parlamentarnych w tym zakresie ${ }^{27}$. Jedną z nich było żądanie natychmiastowej reformy szkolnictwa w duchu katolicko-narodowym, która uwzględni nauczanie Kościoła i doprowadzi do:

a. „Usunięcia wszystkich bezbożników i żydów od wpływu na nauczanie i wychowanie młodzieży katolickiej; a dalej

b. uzgodnienia na sesjach pedagogicznych nauki religii z nauką innych przedmiotów;

c. powołania na stanowiska odpowiedzialne w administracji szkolnej i powierzania kierownictwa zakładów wychowawczych wypróbowanym katolikom;

d. wycofania obecnych podręczników, a zastąpienia ich nowymi, przenikniętymi ideologią katolicką i narodową;

e. jasnego określenia zasad wychowania religijno-moralnego w duchu zasad etyki katolickiej;

f. wezwania wszystkich szczerych katolików nauczycieli, aby starali się stanąć na czele wszystkich organizacji młodzieży szkolnej dla przeniknięcia ich duchem katolickim i narodowym"28.

Należy ponadto zauważyć, że w tym samym czasie redakcja czasopisma dokonała analizy programów kształcenia nauczycieli, stwierdzając, że w liceach pedagogicznych, pedagogiach i na uniwersytetach wychowuje się przyszłych wykładowców „dla dzieci rodziców-niekatolików, bezwyznaniowców lub religijnie obojętnych", gdyż polecana w trakcie studiów literatura jest merytorycznie sprzeczna z doktryną katolicką. Jako przykład wymieniono dzieła A. Comte’a, J. Jamesa, I. Kanta, J. J. Rousseau, G. Kerschensteinera, H. Pestalozziego i W. Spasowskiego. Nie zgadzając się na laickość wykształcenia przyszłych nauczycieli, sformułowano do władz oświatowych następujący apel: „Istniejący obecnie tak zasadniczy rozdźwięk między teorią państwowych przepisów a praktyką pedagogicznych uczelni musi być usunięty. A więc przede wszystkim czynniki decydujące muszą zwrócić uwagę na zasadniczy pewnik, iż polskie szkoły pedagogiczne nie potrafią żadną miarą wychować chrześcijańskich pedagogów młodzieży szkół powszechnych i średnich za pomocą pedagogiki niechrześcijańskiej, czerpiącej pełnymi rękoma ze źródeł niechrześcijańskich czy nawet antychrześcijańskich. Albo więc trzeba zrezygnować z państwowego programu wychowawczego, co stało by w sprzeczności z konstytucją i wolą narodu, albo zdecydować się na reformę ideową pedagogicznych uczelni"29.

Mniej radykalną propozycją był postulat stopniowego zastępowania szkół symultannych szkołami wyznaniowymi dla uczniów określonej konfesji. Rozwiązanie to nie tylko uważano za zgodne z zasadami demokratycznego państwa, ale także jako sposób na walkę z ugrupowaniami politycznymi głoszącymi poglądy, że dominacja religii katolickiej w instytucjach oświatowych jest pogwałceniem

27 Zob. np. L. S k o c z y la s, Szkoła przyszłości, PP 1937, t. 214, s. 164-165; t e n ż e, Szkoła jako czynnik wychowania moralnego, PP 1936, t. 212, s. 14-26.

${ }^{28}$ Te nż e, Szkoła przyszłości..., s. 174.

${ }^{29}$ W. J a s i ń s k i, Kwadratura koła w polskiej pedagogice, PP 1937, t. 216, s. 156. 
praw dzieci innych narodowości i wyznań, a także wolnomyślicieliº ${ }^{30}$ Odwołując się do oficjalnych danych statystycznych, dotyczących wiernych poszczególnych religii, w pierwszej kolejności proponowano jak najszybsze tworzenie szkół konfesyjnych dla wszystkich dzieci wyznania mojżeszowego. O ważności narodowego nakazu takiego rozstrzygnięcia jeden z publicystów „Przeglądu Powszechnego” pisał następująco: „[...] przedstawia same strony dodatnie a żadnej ujemnej. Usuwa wszystkie złe strony oddziaływania młodzieży żydowskiej na polską (rozkład pojęć moralnych, przedwczesne rozbudzenie seksualne, szerzenie idei komunistycznych, ateizmu, atmosfera walki i nieufności w klasie itd.), natomiast nie pociąga żadnych strat za sobą, gdyż asymilacja mas żydowskich do polskości nie jest ani możliwa, ani przez polskie społeczeństwo pożądana"31.

Wypowiadając się natomiast na temat szkół wyznaniowych dla dzieci ewangelików, w „Przeglądzie Powszechnym” radzono, aby w tym przypadku zachować szczególnego rodzaju ostrożność i brać pod uwagę kilka istotnych okoliczności. Po pierwsze, wyznawcy tej religii w Polsce żyją najczęściej w dużym rozproszeniu i tylko w kilku przypadkach są ich większe skupiska. Po drugie, nie identyfikują się z jedną konkretną narodowością, choć najczęściej przyznają się do niemieckiej. Po trzecie, społeczność ta jest organizacyjnie bardzo zróżnicowana, bo jej gminy i zbory opierają się na dużej autonomii i w zależności od tego, czy składają się z Niemców, czy Polaków, z chłopów, czy z mieszczaństwa przejawiają odmienne poczucie narodowej tożsamości. Po czwarte wreszcie - całe grupy ewangelików często pozostają pod daleko idącym wpływem niemieckiego nacjonalizmu, który po dojściu Hitlera do władzy zagraża bezpieczeństwu i pokojowi całej Europy ${ }^{32}$.

Największy problem dostrzegano w tworzeniu szkół wyznaniowych na wschodnich ziemiach Drugiej Rzeczypospolitej. Tłumaczono, że ludność zamieszkująca te terytoria składa się z dwóch niemal jednakowo licznych grup unitów i prawosławnych. Biorąc pod uwagę, że ci pierwsi to także katolicy, tylko innego rytuału, nie widziano potrzeby tworzenia dla nich odrębnych szkół wyznaniowych, ponieważ rodzaj obrządku nie zmienia - jak wyjaśniano -,jedności dogmatycznej i co za tym idzie jedności całego światopoglądu religijnego". Stąd twierdzono, że wspólna szkoła wyznaniowa może i musi objąć jednych i drugich katolików, uwzględniając jednak ich różnice liturgiczne poprzez organizację dla uczniów obu obrządków osobnych zajęć z religii i praktyk religijnych. Przekonując do tego rozwiązania, pisano: „[...] w żadnym razie nie pogorszy stanu narodowego, a nawet dać może duże korzyści, jeśli się zważy, że dopuszczenie duchowieństwa grecko-katolickiego do współodpowiedzialności za szkołę, wzmoże zaufanie do szkoły powszechnej wśród ludności, uważającej się za Ukraińców. Istotna jednolitość szkoły katolickiej wspólnej obu obrządkom zależy wszakże od czynników znajdujących się poza szkołą, a przede wszystkim od tego czy obrządek grecki przyjmie kalendarz gregoriański i zgodzi się na stosowanie alfabetu

${ }^{30}$ E. Ko s i b o w i c z, Sprawy Kościoła. Rozprzężenie moralne..., s. 251.

${ }^{31}$ W. W a s i u t y ń s k i, Szkoła wyznaniowa a narodowa jednolitość państwa, PP 1937, t. 215, s. 197 .

32 Tamże, s. 197-199. 
łacińskiego, jak był on stosowany przez ten obrządek przed stu laty na ziemiach W. Ks. Litewskiego. Wspólny kalendarz i alfabet dałyby istotną wspólność szkoły katolickiej na terenie całego państwa"33. Odmiennie natomiast odnoszono się do sprawy szkoły wyznaniowej prawosławnej, twierdząc, że zbyt wczesne oddanie władzy nad edukacją dzieci i młodzieży klerowi tej konfesji, który w większości jest rosyjski i od czasu schizmy cywilizacyjnie pozostaje obcy wobec narodu polskiego, mogłoby nie tylko doprowadzić do niebezpiecznie głębokich podziałów narodowościowych, ale przede wszystkim do szerzenia komunistycznej ideologii wśród uczniów na Kresach.

Redakcja „Przeglądu Powszechnego” wyrażała negatywny stosunek do głoszonych wówczas poglądów i działań, których celem było odsunięcie rodziny oraz Kościoła od wpływu na szkolnictwo. Nie negowano prawa państwa do tworzenia sieci szkół, bo dzięki tej aktywności rozszerza się zakres dostępu do wykształcenia, ale sprzeciwiano się wszelkim próbom zmierzającym do zastępowania szkół prywatnych i kościelnych szkołami państwowymi ${ }^{34}$. Z jednej strony przestrzegano, że dążenie w takim kierunku wywodzi się z totalitarnych doktryn i w praktyce zawsze doprowadza do sytuacji, że wychowanie w takiej szkole staje się tresurą i musztrą „posłusznych pionków” panującego systemu państwowego ${ }^{35}$, z drugiej natomiast wskazywano, że edukacja wymaga stałości zasad i jej kierunek wychowawczy nie może zależeć od często zmieniających się ekip partyjnych rządzących krajem ${ }^{36}$. Stąd postulowano, aby osobę kierującą sprawami oświaty wyłaniano wyłącznie spośród fachowców w tej dziedzinie, którzy są mniej podatni na naciski polityczne i w swojej działalności będą kierować się przede wszystkim wiedzą i kompetencjami merytorycznymi. Dowodzono: „Ministerstwo oświaty jest od administracji szkolnictwa, żeby panowały w nim porządek, prawość, praworządność i żeby względy wyłącznie pedagogiczne miały w nim wyłączne panowanie. Tego ma minister przestrzegać, a nie wmawiać w siebie i w nas, jakoby był

33 Tamże, s. 200-201.

34 Zob. np. E. Ko s i b o w i c z, Sprawy Kościoła. Rozprzężenie moralne..., s. 250-251; t e n ż e, Sprawy Kościoła. W kwestii monopolu szkolnego. Zagrożony los prywatnego szkolnictwa w Polsce, PP 1933, t. 200, s. 296-304.

35 Zob. np. S. P o d o l e ń s k i, Wychowawczo-oświatowa akcja socjalizmu w Polsce, PP 1928, t. 177, s. 258-272 i t. 178, s. 282-305; Sprawy Kościoła. Na marginesie mowy ministra Jędrzejewicza w komisji budżetowej sejmu, PP 1933, t. 197, s. 239-241; E. K o s i b o w i c z, Sprawy Kościoła. Program „państwowego wychowania” etapem walki o przyszłość, tamże, t. 198, s. 383-390; J. R o s t w o r o w s k i, Sprawy Kościoła. Reforma ustroju a katolicka nauka o pochodzeniu władzy państwowej, PP 1934, t. 201, s. 342-344.

36 Zob. np. M. K u z n o w i c z, O duszę dorastającej młodzieży, PP 1920, t. 145-146, s. 39-48; S. P o d o l e ń s k i, O duszę młodzieży, PP 1925, t. 167, s. 193-209; t e n ż e, Wódz polskiej młodzieży, PP 1926, t. 172, s. 158-173; A. B u k o w s k i, Religijno-moralny rozwój człowieka, PP 1929, t. 182, s. 3-20; J. U r b a n, W poszukiwaniu człowieka, PP 1934, t. 201, s. 171-195; L. S k o c z y I a s, Szkoła jako czynnik wychowania moralnego, PP 1936, t. 212, s. 14-26; L. C h m a j, Pius XI, wychowawca ludzkości, PP 1939, t. 222, s. 3-19; A. N i e s i o ł o w s k i, Struktura wewnętrzna katolickiej ideologii wychowawczej, tamże, t. 221, s. 328-351; t e n ż e, Założenia poznawcze katolickiej ideologii wychowawczej, PP 1939, t. 222, s. 50-67; t e n ż e, Założenia aksjologiczne katolickiej ideologii wychowawczej, tamże, s. 191-208, t e n ż e, Katolickie koncepcje wychowawcze w starożytności i średniowieczu, tamże, t. 223, s. 19-46. 
personifikacją pedagogii! Osiągnięcie urzędu ministra oświaty nie mieści w sobie osiągania wiedzy pedagogicznej ... na poczekaniu ... ॥z urzędu«! [...] w tym oto absurdzie zawiera się główne zło. Na czele szkolnictwa niech stoi pedagog a nie polityk, koślawiący pedagogię! Naczelnik oświaty publicznej musi być równy ministrom, żeby być od nich niezależnym; ale ministrem być nie powinien, żeby nie upadać razem z gabinetem, żeby nie zarażać szkolnictwa trzęsieniem ziemi. Co ma pedagogia z gabinetem! Póki się nie otrzęsiemy z tego przesądu, nie wybrniemy z błędnego koła. Albowiem szkoła nie jest politicum i nie ma pedagogii państwowej" ${ }^{37}$.

Równolegle z przedstawianym postulatem dotyczącym odpolitycznienia szkolnictwa, na łamach „Przeglądu Powszechnego” krytykowano decyzje ministerialne, które przynosiły negatywne następstwa nie tylko dla bezpośrednich odbiorców edukacji, ale i całego społeczeństwa. Do takich zaliczano w pierwszej kolejności ustawę dotyczącą zakładania i utrzymywania publicznych szkół powszechnych oraz ustawę o budowie publicznych szkół powszechnych ${ }^{38}$. Jej zapisy nie tylko traktowano jako niewykonalne z powodu braku odpowiednich funduszów, ale uważano za szkodliwe dla realizacji zasady powszechnego nauczania, gdyż gminom, które z powodów finansowych nie były w stanie wznosić okazałych gmachów szkolnych, zabraniały stawiać skromniejsze budynki szkolne i tym samym stawały na przeszkodzie w powiększaniu liczby szkół ${ }^{39}$. Negatywne skutki takiej legislacji polska oświata szczególnie doświadczała w latach trzydziestych XX w., kiedy państwo było zmuszone radykalnie zmniejszyć wydatki na edukację, które z jednej strony polegały na obniżaniu kwot przeznaczanych na szkolnictwo powszechne, z drugiej - na przerzucaniu wszystkich zobowiązań związanych z utrzymywaniem szkół na budżety samorządów terytorialnych ${ }^{40}$. Wymuszona przez kryzys gospodarczy strategia zarządzania oświatą zbiegła się w czasie z przyrostem liczby dzieci w wieku szkolnym, które ze względu na brak izb lekcyjnych i niewystarczającą liczbę etatów nauczycielskich nie mogły znaleźć dla siebie miejsca w obowiązkowej szkole powszechnej ${ }^{41}$. Oceniając w czaso-

${ }^{37}$ F. K o n e c z n y, Uwaga o szkolnictwie państwowem, PP 1930, t. 186, s. 21-22.

38 Obie ustawy Sejm uchwalił 17 lutego $1922 \mathrm{r}$.

39 S. P o d o le ń s k i, Kryzys naszego szkolnictwa powszechnego, PP 1936, t. 209, s. 350.

40 Zob. np. K. Trze b i a to w s k i, Szkolnictwo powszechne w Polsce w latach 1918-1931, Wrocław-Warszawa-Kraków 1970, s. 272-284; W. G a r b o w s k a, Szkolnictwo powszechne w Polsce w latach 1932-1939, Wrocław-Warszawa-Kraków-Gdańsk 1976, s. 129-160; D. N a ł ę c z, Kultura Drugiej Rzeczypospolitej, Warszawa 1991, s. 12-15; G. M i c h a I s k i, Obraz kryzysu szkolnictwa powszechnego lat trzydziestych XX wieku w czasopismach organizacji nauczycielskich, [w:] Przełomy edukacyjne. Dziedzictwo polskiej teorii i praktyki, red. W. S z u l a k i e w i c z, Toruń 2011, s. 220-232.

${ }^{41}$ Stosunek procentowy liczby uczniów w wieku obowiązku szkolnego do liczby dzieci podlegających obowiązkowi szkolnemu w okresie kryzysu gospodarczego w poszczególnych latach szkolnych wynosił: 1929/1930 - 94,6; 1930/1931 - 93,6; 1931/1932 - 92,2; 1932/1933 - 93,5; 1933/1934 - 92,3; 1934/1935 - 91,2; 1935/1936 - 88,3. Zob. J. M i ą s o (red.), Historia wychowania wiek XX, t. 1, Warszawa 1980, s. 75. Należy zauważyć, że w roku szkolnym 1935/1936 zabrakło w szkołach miejsc dla 600 tys. dzieci w wieku szkolnym, a biorąc pod uwagę, że część uczniów przerywała edukację w ciągu roku, liczba ta była bliska miliona. Jadwiga Zanowa tak na ten temat pisała w swoim pamiętniku: „Sytuacja zamiast się poprawiać, zaczęła się gwałtownie pogarszać, gdy w początku 1930 r. o szkołę uderzyła fala zwiększonego przyrostu naturalnego powojennych roczników. Ministerstwo WRiOP nie 
piśmie zaistniałą sytuację, twierdzono, że plan kształcenia wszystkich uczniów w siedmioklasowej szkole powszechnej był bardzo ambitny i pożądany, ale w polskich warunkach dalece przedwczesny i zupełnie nierealny. Utrzymywano, że nie powstał on z troski o upowszechnienie wykształcenia, lecz z dbałości o interesy polityczne jego twórców ${ }^{42}$. Przede wszystkim wskazywano na działaczy lewicy nauczycielskiej, reprezentowanej głównie przez Związek Polskiego Nauczycielstwa Szkół Powszechnych i Związek Zawodowy Nauczycielstwa Polskich Szkół Średnich (w latach późniejszych ZNP), które głosiły hasła szkoły jednolitej, obowiązkowej, jednakowej w sensie programowym i organizacyjnym dla wszystkich dzieci, bez względu na ich pochodzenie społeczne i miejsce zamieszkania. Koncepcję tę nazywano arystokratyczną, bo jej skutkiem - pisano w czasopiśmie połowie lat trzydziestych - było podniesienie stopnia organizacyjnego szkół kosztem powszechności nauczania, co doprowadziło do sytuacji, że jedne dzieci były uprzywilejowane, a drugim „nie pozwolono nawet uczyć się czytać i pisać”. Zaświadczać o tym miały przywołane dane, z których wynikało, że w roku 1929/1930 w stosunku do roku 1922/1923 zlikwidowano przeszło półtora tysiąca publicznych szkół powszechnych. Do autorów tak radykalnych rozwiązań w szkolnictwie kierowano słowa: „Postawiwszy sobie trzy punkty do równoczesnego zrealizowania; powszechność nauczania, wysoki stopień organizacyjny szkolnictwa powszechnego i «jednolitość szkolnictwa» w ogóle, poświęcili pierwszy, najważniejszy dla społeczeństwa punkt, żeby przeforsować dwa następne - i w rezultacie zaprzepaścili wszystko. Dziś nie tylko nauczanie nie jest powszechnym, ale wysoki poziom organizacyjny nie istnieje, a jednolitość szkolnictwa stała się fikcją [...]"43. Realizowaną ideę ustroju szkolnego obrazowo porównywano do pomysłu szlachcica, który postanowił wybudować pałac godny jego rodu, i położył stosowne fundamenty, nie mając jednak na razie środków finansowych, posadowił na nich skromny dworek drewniany, w którym nie tylko on dokończył pracowitego żywota, ale także jego potomkowie, bo nigdy nie byli w stanie wznieść pałacu.

Kiedy jesienią 1927 r. minister G. Dobrucki przedstawił do publicznej dyskusji przygotowany przez jego resort projekt ustawy o ustroju szkolnym ${ }^{44}$, publicyści „Przeglądu Powszechnego” zaprezentowali własną koncepcję zmian w oświacie. Biorąc pod uwagę skutki wcześniejszych decyzji dotyczących oświaty, a także uwarunkowania i możliwości ekonomiczne kraju, wyrażono pogląd, że rozwój szkolnictwa powinien zmierzać w kilku kierunkach. Po pierwsze, należy porzucić program maksymalny, który - jak przekonywano - będzie możliwy do wykonania

przygotowało na ten okres ani kadr nauczycielskich, ani nowych izb lekcyjnych. Poza szkołą znalazło się około miliona dzieci”. J. Z a n o w a, W służbie oświaty. Pamiętnik z lat 1900-1946, Wrocław 1961, s. 360 .

42 Zob. S. P o d o l e ń s k i, Kryzys naszego szkolnictwa..., s. 352.

43 Tamże, s. 355.

${ }^{44} \mathrm{~W}$ dokumencie podstawą systemu oświatowego uczyniono siedmioletnią i siedmioklasową szkołę powszechną. Na niej oparto szkoły średnie ogólnokształcące trzy- i pięcioletnie $(7+3$ lub 7+5). Edukacja zawodowa tworzona być miała na bazie szkoły powszechnej lub trzech klas szkoły średniej ogólnokształcącej. Dla młodzieży niepodejmującej nauki w szkole średniej przewidywano także obligatoryjne dokształcanie do 18. roku życia. Zob. Ustawa o ustroju szkolnictwa. Projekt Komisji powołanej przez Ministra WRiOP, Warszawa 1927. 
za dziesiątki, a może i setki lat, i powrócić do programu minimum, czyli na tych terenach, gdzie już funkcjonują szkoły powszechne zadbać o to, aby podnosić ich stopień organizacyjny, jeśli tylko istnieją takie potrzeby i są zapewnione środki na pokrycie tych zadań. Po drugie, tam, gdzie nie ma szkół powszechnych, należy tymczasowo zakładać szkoły jednoklasowe, nawet w każdej wsi, aby walczyć ze szkodliwym dla społeczeństwa analfabetyzmem ${ }^{45}$, natomiast w przyszłości, kiedy warunki gospodarcze na to pozwolą, szkoły te przekształcać w placówki wysoko zorganizowane ${ }^{46}$. Po trzecie, należy bezwzględnie popierać szkoły dopełniające, kursy dla dorosłych analfabetów, szkoły rolnicze, rękodzielnicze i gospodarstwa domowego. Po czwarte, trzeba zachować zasadę ${ }^{47}$, przechodzenia uczniów zdolniejszych do szkoły średniej po ukończeniu czwartej klasy szkoły powszechnej i zdaniu egzaminu wstępnego, a także uczniom uzdolnionym ze szkół więcej niż czteroklasowych do odpowiedniej klasy szkoły średniej. Po piąte, szkoła średnia powinna być sześcioklasowa (liceum) jednego typu dla wszystkich (z małymi zmianami dla dziewcząt), ogólnokształcąca, z językiem łacińskim od trzeciej lub czwartej klasy, z programem - jak określano - umiarkowanym. Dawałby on wystarczającą podstawę do szkół zawodowych wyższych, na przykład: dwuletniego zakładu kształcenia nauczycieli, szkół handlowych, przemysłowych, kolejowych, wojskowych, szkół przygotowujących do praktyki pocztowej. Z kolei dla najzdolniejszych uczniów przewidywano przejście do gimnazjum trzyklasowego w dwóch odmianach: filologicznego z łaciną i greką, a także językiem nowożytnym oraz matematyczno-przyrodniczego ze znaczną przewagą tych przedmiotów. Pierwsi uzyskiwaliby przygotowanie do studiów wyższych na wydziale teologicznym, prawniczym, filozoficznym, filologicznym i historycznym, drudzy natomiast - na wydziale lekarskim, nauk przyrodniczych, rolniczych, a także górniczych i technicznych ${ }^{48}$.

Dla redaktorów „Przeglądu Powszechnego” wprowadzona w 1932 r. przez Janusza Jędrzejewicza reforma ustroju szkolnego była nieuzasadnioną i szkodliwą dla edukacji Polaków przebudową systemu oświaty, która w imię haseł politycznych i ideologicznych rozbiła szkolnictwo na trzy typy szkół: siedmioklasową szkołę powszechną, czteroletnie gimnazjum i dwuletnie liceum, zaprzepaszczając tym samym dalszą możliwość kształcenia uczniów szczególnie uzdolnionych intelektualnie w dłuższym i nierozdzielnym organizacyjnie okresie czasu. Dowo-

${ }^{45}$ Szeroką analizę zjawiska analfabetyzmu w Polsce międzywojennej jako czynnika utrudniającego rozwijanie czytelnictwa wśród dzieci i młodzieży znaleźć można [w:] I. M i c h a I s k a, Wychowanie do czytelnictwa uczniów szkół powszechnych w Drugiej Rzeczypospolitej, Łódź 2011, s. 43-52. Autorka ta podaje, że z przeprowadzonego w 1931 r. spisu powszechnego wynikało, że 23,1\% mieszkańców Polski powyżej 10. roku życia było analfabetami. Odsetek niepiśmiennej ludności wiejskiej wynosił 27,6\%, natomiast miejskiej - 12,2\%. Najwyższy poziom analfabetyzmu był na kresach wschodnich: w województwie poleskim - 48,4\%, wołyńskim - 47,8\% i stanisławowskim $-36,6 \%$. Natomiast najniższy w województwach: śląskim $-1,5 \%$, poznańskim $-2,8 \%$ i pomorskim $-4,3 \%$.

46 S. Podoleński, Krytyczne położenie szkolnictwa powszechnego w Polsce, PP 1931, t. 192, s. 397; t e n ż e, Kryzys naszego szkolnictwa..., s. 349-351.

47 F. B i e I a k, Z dyskusji o ustrój szkoły średniej, PP 1928, t. 178, s. 136-149.

${ }^{48}$ R. Z a w i l i ń s k i, Nowa szkoła w nowej Polsce, PP 1929, t. 182, s. 24-25 i 42-43. 
dzono, że szkoła średnia, tracąc dwa pierwsze lata na rzecz szkoły powszechnej mającej do osiągnięcia swoje własne cele oraz tracąc dwa ostatnie lata na rzecz liceum, któremu także przypisano własne zadania, nie dysponuje już odpowiednią ilością czasu na pełne, systematyczne i całościowe przeprowadzanie kształcenia i stosuje dydaktyczną zasadę wyboru treści nauczania nawet $w$ tych sytuacjach, w których z góry wiadomo, że dla końcowych efektów edukacji jest to niesłuszne i szkodliwe. Zastanawiając się, jak i w jaki sposób przeciwdziałać dalszemu upadkowi średnich szkół ogólnokształcących, sformułowano następujący postulat: „Nie widzimy innego wyjścia z tej fatalnej sytuacji poza powrotem 8-klasowego, a przynajmniej 6-klasowego gimnazjum. Straszna będzie odpowiedzialność dziejowa tych, którzy ubogą Polskę narazili na tak niebezpieczne i tak kosztowne doświadczenia! Znajdują się pieniądze na te eksperymenta, a nie ma ich na budowę szkół ludowych, na etaty dla nauczycieli, na zwalczanie analfabetyzmu. Będziemy mieli [...] «postępowe» licea i równocześnie największy procent analfabetów w Europie. Powie może ktoś, że takie ujmowanie sprawy, że takie zestawienia to demagogia. Nie, to tylko odwaga spojrzenia prawdzie w oczy i odwaga wypowiadania tej prawdy"49.

Zainteresowanie aktualnymi problemami oświaty oraz edukacji dzieci i młodzieży redakcja „Przeglądu Powszechnego” traktowała jako naturalny obowiązek, który z jednej strony wynikał z historycznych doświadczeń Zakonu Jezuitów prowadzącego od dziesiątków lat własne szkoły i konwikty, z drugiej natomiast z zadań postawionych w tej dziedzinie przez Kościół katolicki, który od wszystkich członków wspólnoty religijnej oczekiwał realizacji w praktyce życia społecznego katolickiego ideału wychowawczego oraz nieustannego i pełnego zaangażowania w dzieło szkolnego nauczania i wychowania młodego pokolenia. Co prawda, formułowane na łamach tego periodyku postulaty dotyczące szkolnictwa generalnie stanowiły odbicie oficjalnego stanowiska Kościoła katolickiego, szczególnie ten dotyczący wprowadzenia w Polsce szkoły wyznaniowej katolickiej, jednak szereg wypowiedzi na tematy oświatowe miały postać niepowtarzalnych rozważań, które przyjmując charakter wszechstronnych i wnikliwych analiz, przyczyniały się do podniesienia merytorycznego poziomu debaty publicznej prowadzonej w tym zakresie przez cały okres międzywojenny.

${ }^{49}$ S. B e d n a r s k i, Na bezdrożach reformy szkolnictwa średniego, PP 1937, t. 214, s. 384. 